\title{
ON THE DORSIVENTRALITY OF THE PODOSTEMACEAE, WITH REFERENCE TO CURRENT VIEWS ON EVOLUTION ${ }^{1}$ -
}

The paper read is an extract from a forthcoming paper in the Annals of the Royal Botanic Gardens, Peradeniya, upon the Morphology and Ecology of the Podostemaceae. This order shows a very far-reaching dorsiventrality of structure, both vegetative and floral. Two lines of argument are followed-one morphological, the other ecological. Commencing with the less modified types found in the order, which show a slight amount of dorsiventrality in the vegetative system and none in the floral, a series is traced through the more modified types, showing the progressive increase in dorsiventrality of the vegetative system followed throughout by an increase in that of the floral, showing first in the spathe and bracts, then in the androeceum, next in the gynaeceum, and lastly in the interior of the ovary. In the next place, the same series, regarded ecologically, shows that though the flowers are steadily more and more zygomorphic-a condition usually regarded as an adaptation to insect visits and accompanied by a horizontal position of the open flower-they at the same time stand stiffly erect, and are more and more anemophilous and autogamous.

The most reasonable explanation of these facts seems to be that the dorsiventrality of the flowers has been forced upon them, without reference to any advantage or disadvantage in the performance of their special functions, by the steadily increasing dorsiventrality of the vegetative system, the latter being due to the general effect of the total conditions of life acting on the hereditary peculiarities of the ancestral forms, whether directly or indirectly. Now the dorsiventrality of the floral organs is a character of high taxonomic value, and upon the various degrees of it the grouping of the Podostemaceae is chiefly founded, while it is always regarded as important in other families. The conclusion drawn is supported by the facts of dorsiventrality in other families, and if admitted as probable opens up a number of new points of view, and raises questions which must be settled one way or the other.

If one character of importance may thus be forced upon an organ or organs without reference to any advantage to that organ in the

1 Abstract of paper read before Section $\mathrm{K}$ of the British Association, Belfast, 1902. 
performance of its functions, it seems only likely that others may; and consequently, that the study of adaptation must enter upon a new phase in connexion with the study of comparative and experimental morphology and of variation and correlation.

Another question raised is the insecurity of our conceptions of genera and other taxonomic groups, and the need of some more quantitative and phylogenetic basis. We divide the Podostemaceae, for example, into genera and sub-orders largely upon the degree of dorsiventrality displayed in the flowers and fruits, but we do not know the real quantitative or phylogenetic value of the distinctions. It also follows from the above conclusion that it is highly probable that many genera, species, sub-orders, or even larger groups, may be polyphyletic. We can easily imagine a group of allied or similar species, for example, all becoming more dorsiventral in their vegetative systems, and at last all of them showing the effect in the floral organs. As the effects in the latter seem to follow very definite rules, all these species may presently form a polyphyletic genus, there being no ancestor which has the generic characters. The same reasoning applies to higher groups, and in the very largest groups we are already beginning to perceive clearly that many, if not most, are more or less polyphyletic. It is evident that this view, if it prove true even in part, will help in clearing up the darkness which surrounds many of the problems of evolution, geographical distribution, \&c.

JOHN C. WILLIS.

Peradeniya.

FOLIAR PERIODICITY IN CEYLON ${ }^{1}$. - The high temperature and humidity of the air in most parts of Ceylon allow almost continuous growth of the arborescent vegetation. There are, however, nearly two hundred species which become leafless at different times of the year.

External and internal factors affect the phenomena of defoliation and foliar renewal. The climatic effect is obvious from the fact that the majority of our deciduous species become leafless during our hottest and driest months. The deciduous trees respond only to one hot dry period of three or four months, and not to the dry part of each monsoon. Some species undergo complete defoliation twice per

1 Abstract of paper read before Section K of the British Association, Belfast, 1902. 


\section{$2 \mathrm{BHL}$ Biodiversity Heritage Library}

Willis, J. C. 1902. "On the dorsiventrality of the Podostemaceae, with reference to current views on evolution." Annals of botany 16, 593-594. https://doi.org/10.1093/oxfordjournals.aob.a088896.

View This Item Online: https://www.biodiversitylibrary.org/item/233980

DOI: https://doi.org/10.1093/oxfordjournals.aob.a088896

Permalink: https://www.biodiversitylibrary.org/partpdf/318697

\section{Holding Institution}

Smithsonian Libraries

\section{Sponsored by}

Biodiversity Heritage Library

\section{Copyright \& Reuse}

Copyright Status: Not in copyright. The BHL knows of no copyright restrictions on this item.

This document was created from content at the Biodiversity Heritage Library, the world's largest open access digital library for biodiversity literature and archives. Visit BHL at https://www.biodiversitylibrary.org. 